\title{
A Guide to Capital Outlays in the Current Recovery
}

\author{
JAI-HOON YANG
}

M the atypically sluggish rebound in real fixed investment expenditures in the current recovery. ${ }^{1}$ Such concern reflects the important role of fixed investment in a dynamic economy - it not only serves to augment the current pace of economic activity, but also influences the sustainability of the economy's upward momentum beyond "recovery."

To understand the sluggish rebound in capital outlays to date and to assess the likely course of such outlays, it is useful to examine the atypically severe decline in capital outlays that preceded the current recovery. A theory of the investment process provides a useful frame of reference in understanding the past evolution of fixed investment outlays and in assessing their prospective course.

The investment process is fundamentally a process of adjusting the firm's existing capital stock to some desired level. The desired capital stock is ultimately determined by expected net return, which is influenced by such factors as sales expectations, the acquisition cost of new capital, the expected cost of employing capital, and business tax considerations. Reflecting downward revisions in expectations of net return (as reflected in capital commitments data), capital outlays plummeted in the most recent recession. ${ }^{2}$ Two factors most responsible for the decline in expected net return appear to be (1) a decline in sales expectations and (2) a rise in the acquisition cost of new capital goods. Both factors are influenced, in turn, by the sudden and unexpectedly sharp increase in the relative price of energy and the cumulative effects of increasingly exacting government regulations.

The anemic rebound in capital outlays in the current recovery can be attributed to the less than robust

\footnotetext{
"See "The Business Situation," Survey of Current Business (October 1976 ), p. 8. Unless otherwise noted, all references to expenditures are in real terms.

The capital commitments data analyzed in the paper are to be found in Series no. 20, "Contracts and Orders for plant and equipment billions of 1972 dollars," U.S. Department of Comm merce, Business Conditions Digest (January 1977). This series is considered a leading indicator of both general economic activty and the achual flow of fixed investment expenditures.
}

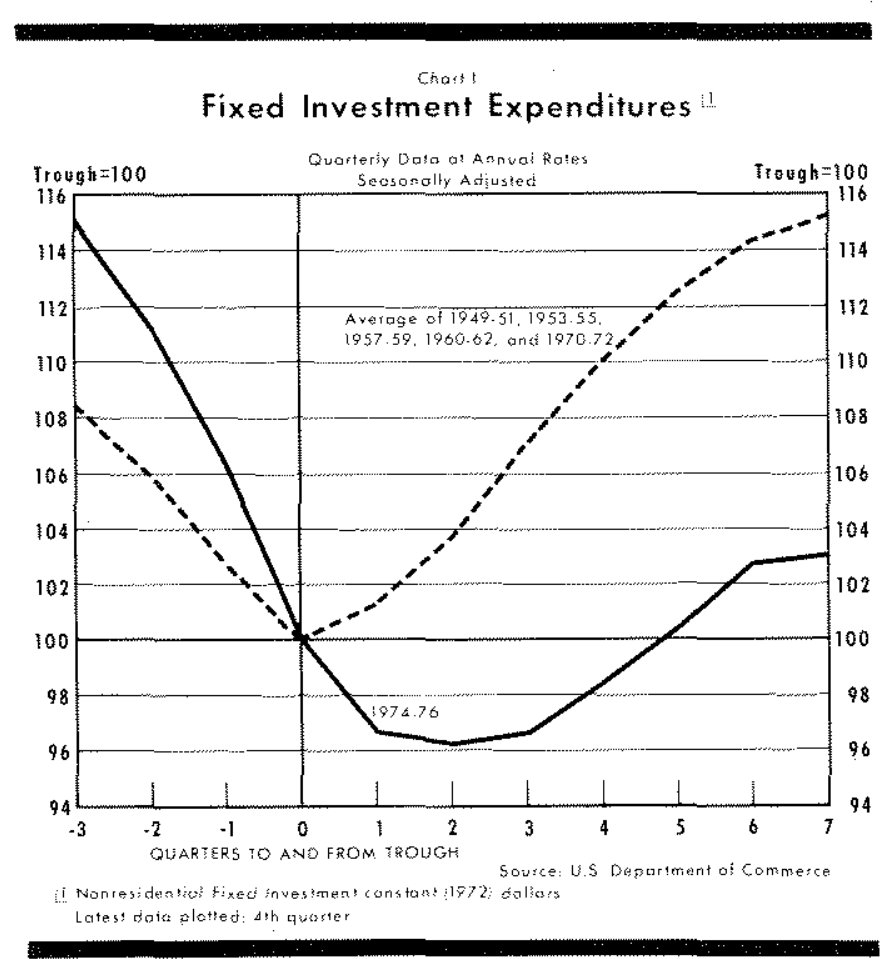

upward revisions in the expected net return on investment, as reflected in investment commitments data. The severity of the preceding recession is partially responsible since it left the balance sheets of many firms in a vulnerable position, as witnessed by the dramatic increase in the incidence of business failures. An additional factor responsible for the sluggish rebound in actual capital outlays has been the systematic shortfalls in capital outlays relative to intended outlays. Such shortfalls appear to be the result of decisions to defer, rather than cancel, investment plans.

The process of rebuilding balance sheet positions appears to have been completed. The rate of increase in the acquisition cost of new capital goods relative to the price of output in general has slowed. In addition, there has been a sustained increase in the utilization rate of both human resources (as measured by the ratio of the number of individuals employed to the population of working age) and capital resources throughout the recovery to date. In view of both these 
developments and the likely "catch-up" of deferred outlays, a sustained but modest upward revision in the desired capital stock relative to the actual stock is expected. Such an upward revision will be reflected in increased investment commitments before it is translated into an increased flow of actual capital expenditures.

\section{THE INVESTMENT PROCESS}

\section{The Decision to Increase Capital Stock}

Capital formation, or investment, entails a sacrifice of present consumption opportunities in return for an expected increase in such opportunities in the future. Since the present is relatively certain whereas the future is not, capital formation involves certain sacrifice currently for uncertain returns in the future. ${ }^{3}$ Therefore, investment decisions are influenced by attitudes toward risk, changes in perception of risks associated with the outcome of investment decisions and, most fundamentally, by expectations of net return.

The expected net return on investment is influenced, in turn, by a complex of such factors as (1) sales expectations, (2) the expected tax treatment of business income, depreciation, and equipment purchases, (3) the acquisition cost of new capital goods, and (4) the expected cost of conforming to environmental and safety regulations. These factors jointly influence the expected value of output relative to the cost of using capital to produce that output and, hence, the investment decision. Attempts to represent the unobserved expected variables by observed proxy variảbles are still at an exploratory stage. Some examples of proxy variables that have been tried are final sales and changes in them, corporate cash flows, capacity utilization rate, value of the firm, corporate bond rate, the ratio of profits to fixed assets, and the tax structure. The estimated link between these variables and investment expenditures continues to be the subject of much controversy. There are as many theories of investment as there are different judgments as to the best empirical proxies for the determinants of the expected net return on investment and, thereby, of the desired capital stock.

\footnotetext{
${ }^{3}$ For a modern restatement and extension of this basic Fisherian view of investment, see Jack Hirshleifer, Investment, Interest, and Capital (Englewood Cliffs: Prentice-Hall, 1970) For the original treatise, see Irving Fisher, The Theory of Interest (New York: Kelley and Millman, Ine, 1954).

4For a survey of such theories, ranging all the way from the naive accelerator to a sophisticated neoclassical theory, see Dale W. Jorgenson, "Econometric Studies of Investment Behavior: A Survey, Joutnal of Economic Literature (December 1971), especially pp. 1128-29.
}

\section{The Timing of Invesment}

General agreement exists, however, that investment at the individual firm level is usefully viewed as an attempt to adjust the firm's existing capital stock to some desired level. Such adjustment takes place over time, both for technological and economic reasons, and therefore, the investment process at the firm level can be viewed as a multi-stage decision process. ${ }^{5}$ First, a decision is made as to whether the actual capital stock differs from the desired capital stock. Next, through such processes as budgeting, appropriations, and actual placing of orders and contracts, the timing of investment expenditures to achieve the desired stock is determined. The actual flow of investment outlays is the final stage in the process and represents the realization of intended investment outlays. "The process is also ongoing in that a continuous reassessment of both the previously determined level of desired capital stock and the timing of investment outlays takes place.

The decision as to the size of the desired capital stock, which is made in the first stage of the process, is revealed by movements of the data on capital investment commitments. ${ }^{7}$ Capital investment commit ments have been found to be a useful indicator of future movements in investment outlays. ${ }^{8}$

The linkage between the commitments and the subsequent investment expenditures is not watertight, however, and three factors appear to account for the slippage: first, outright cancellations of orders and contracts; second, deferral of orders; and third, supply constraints in the capital goods sector which delay the delivery of orders and construction of plants on time.

WThe paper by forgenson cited above also surveys various empirical attempts to represent the time structure of the investment process by various distributed lag functions (such as the geometric and rational). See Jorgenson, "Econometric Studies," pp. $1134-38$.

GFor a discussion of the various stages of the investment process, see Victor Zamowitz, Orders, Production, and Investment - A Cyclical and Structural Analusis (New York: National Bureau of Economic Research, 1973), especially Chapter 9 . For an analysis of realization of intended investment outlays, see Robert Eisner, "Realization of Investment Anticipations," The Brookings Quarterly Model of the United States, ed. James S. Duesenberry, Gary Fromm, Lawrence R. Klein and Edwin Kuh (Amsterdam: North-Hollaxd, 1965), pp. $95-128$.

${ }^{7} \mathrm{~A}$ variable such as capital investment commitments is known as a symptomatic variable for irvestment expenditure, as opposed to such causal variables as final sales, corporate profits after taxes, corporate cash flow, capacity utilization rate and the price of capital services (which often are used as proxies for the expected retum).

${ }^{8}$ See Zarnowitz, Orders, Production, and Investment, pp. 465-75. 
The first factor, cancellation, reflects a reassessment of decisions reached at the first stage of the investment process - that is, an adjustment downward in the level of the desired stock of capital. Such a reassessment would be triggered by a deterioration in the perceived profitability of investment and would be reflected in a decrease in outstanding investment commitments. However, the second factor, deferral, reflects changes in the timing of investment rather than any substantial revisions in the desired stock of cepital. Any firmly-held expectation of imminent changes in government policy, such as an increase in the investment tax oredit, for example, will affect the deferral decision. The third factor, based on supply constraints, is qualitatively different from the first two in that the shortfall in actual investment outlays relative to commitments is likely to reflect an excess rather than a deficient aggregate investment demand.

\section{CAPITAL INVESTMENT DURING THE DOWNTURN}

The decline in real plant and equipment investment in the most recent recession has been the severest of all the postwar cycles in terms of both magnitude and duration. ${ }^{*}$ The steep decline in plant and equipment spending was signalled by a steep decline in capital investment commitments, as shown in Chart II. The commitments data indicate the extent of deterioration in business expectations about the profitability of investments during the most recent recession. The downturn in investment spending, measured at constant prices, in the 1973-75 recession was as severe, for example, as in the 1957-58 downtum. However, investment commitments fell much more sharply in the most recent downturn, indicating a sharp deterioration in the prospective return on investments that had not characterized prior periods of economic recession.

\section{The Impact of Exogenous Shocks}

The sharp decline in the commitments data suggests that the discrepancy between the desired and the actual stock of capital fell sharply in the recent recession. This fall in the desired relative to the actual capital stock is traceable to adjustments made by both

The nomresidential fixed investment (NRFI) component of GNP is composed of the producers' durable equipment and "construction other than residential nonfarm" conponents of the national income accounts. Business fixed investments (BFI) is arrived at by excluding from NRFI farm equipment and construction, construction by private nonprofft institutions, capital outlays charged to current expenses and capital outlays of independent professionals. The movements in the two series (NFRI \& BFI) are statistically indistingutishable, however.

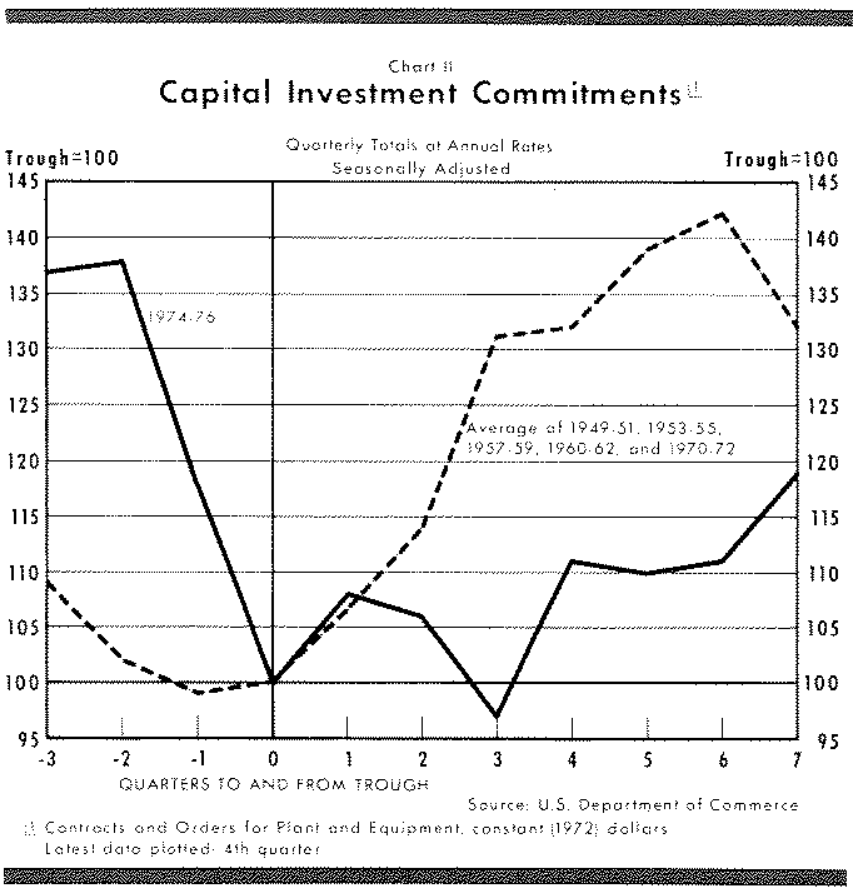

the producers and potential buyers of newly produced capital goods to external shocks, such as the quadrupling in oil prices and increasingly stringent regulatory mandates. Both factors have caused a drastic and largely unexpected increase in the cost of using many existing productive facilities and technology. Such an increase in cost reduces the observed utilization rate of the existing capital stock and, holding other factors constant, increases the demand for netw capital goods that embody more energy-efficient and regulationconforming technologies. The observed utilization rate of productive capacity would have a downward bias to the extent that it does not fully reflect the accelerated economic obsolescence of the existing capital stock. ${ }^{10}$

If the economy in general, and the buyers and producers of eapital goods in particular, had made adjustments to these shocks instantaneously and without cost, there would not have been any decrease in the utilization of labor and capital resources. ${ }^{11}$ There would simply have been a shrinkage in the size of capacity output. However, such costless and instantaneous adjustments are not possible in the world we

10For an analysis which presents significant indirect evidence corroborating the view that there is such a downward bias, see Denis S. Kamosky, "The Link Belween Money and Prices - 1971-1976," this Review (Jume 1976), pp. 17-23.

11 The adjustment was complicated by the world-wide repercussions of the energy-price rise and other fortutous factors. For a detailed analysis of the various canses of the most recent recession, see Noman $\mathrm{N}$. Bowsher, "Two Stages to the Current Recession," this Reciew (June 1975), pp. 28. 
live in, which is characterized by: (1) imperfect information regarding market and productive opportunities, (2) resistence to and constraints on downward adjustments in real wages which would have been necessary to conform to the reduction in the capitallabor ratio and the size of the total output, and (3) less than perfectly malleable capital.

In such a world, a sudden and unexpected acceleration in the obsolescence of existing capital stock in" duces an increase in the unemployment of labor during the adjustment period. ${ }^{12}$ The increase in unemployment tends to generate, in turn, a decline in income and employment prospects of both the employed and the newly unemployed workers. Precautionary belt-tightening ensues, as reflected in deterioration in the index of consumer sentiment and a decline in the volume of retail sales. This in turn causes business to become skeptical about sales prospects and tends, for a time at least, to dampen demand for new capital. The desire to replace obsolete capital tends to be dominated by overall pessimism about the profitability of even the new capital. A further adverse feedback effect on the capacity utilization rate and the desired stock of capital ensues.

The steep decline in the composite index of sensitive financial flows during the recent downturn is indicative of such a deterioration in near-term income and employment prospects. This induces nonbusiness economic units to tighten belts and attempt to strengthen their balance sheet positions to cope with the "foreseeable" contingencies (Chart III) ${ }^{13}$ Such a retrenchment by nonbusiness economic units would adversely affect near-term business expectations of net return on investment.

\section{Impact of Capital Goods Prices}

The behavior of the price and quantity of newly produced capital goods during the recent downswing suggests that the rise in the supply price of new capital goods also had a depressing effect on the

$1 \pm$ Such an increase in unemployment is triggered by the decline in the demand for labor induced by a reduction in the effective capital stock consequent to the accelerated obsolescence of existing capital stock. If capital were perfectly malleable, capital could not becone obsolete.

${ }^{13}$ The Department of Commerce recently revised some of its data series published in the Bustness Conditions Digest. The Composite Index of Sensitive Financial Flows was renamed the Composite Index of Money and Financial Flows and its components changed. Previously composed of changes in consumer installment debt, business loans, mortgage debt and money supply (M1) in current dollars, it currently is made up of changes in total liquid assets (M7), M1 in 1972 dollars, and total private borrowings.

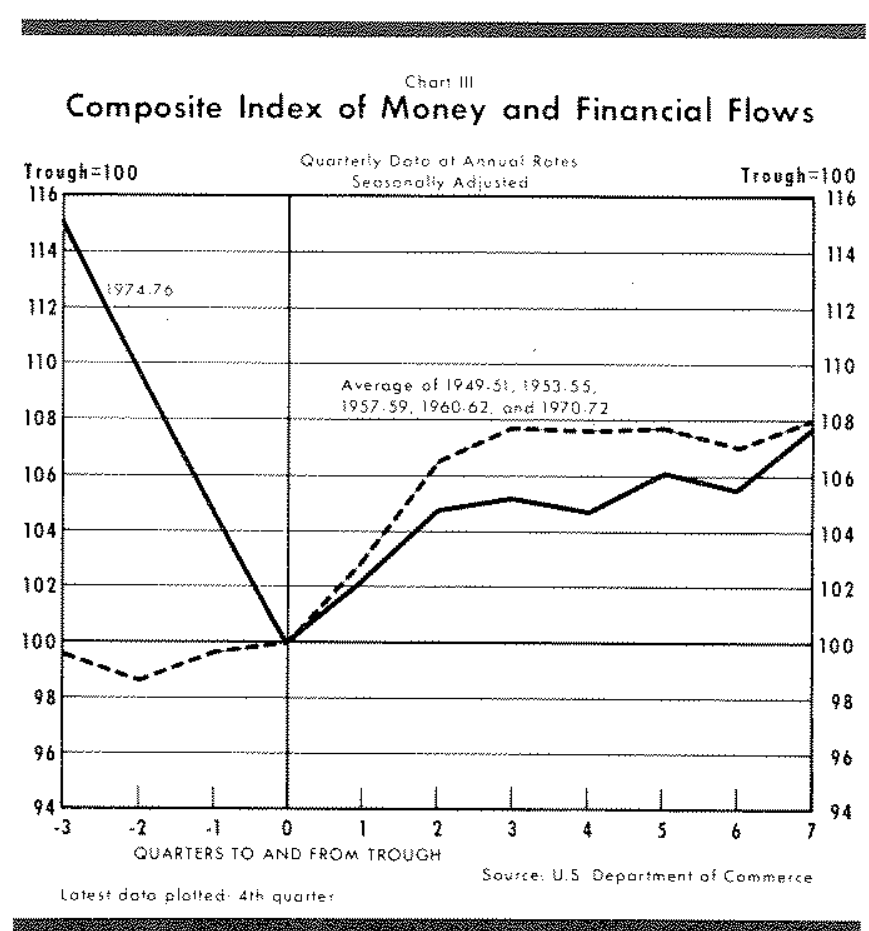

desired stock of capital. Two factors impinging on the producers of new capital goods - (1) the cost of adopting and embodying more energy-efficient technologies and (2) the cost of conforming to the myriad regulatory mandates - added substantially to the cost of producing capital goods, thereby reducing the supply of new capital goods. ${ }^{14}$

The price of new capital goods escalated at a substantially faster rate than that of goods in general throughout the whole period of recession (Chart IV). Such an occurrence is unprecedented in the postwar period and tends to dampen the quantity of additional capital demanded. The fundamental reason for this, of course, is that higher and rising prices of new capital goods, when not matched by optimistic expectations of higher and rising future net revenue streams from these goods, reduce the expected net return on investment.

An alternative way to characterize the "ultimate" determinant of the desired capital stock and the entailed investment spending is in terms of the discrepancy between the price of existing capital goods and the cost of reproducing them. ${ }^{15}$ We do not as yet

14Fon a documentation if the increase in the cost of conforming to regulatory constraints, see Murray $\mathrm{L}$. Weidenbaum, Government-Mandated Price Increases; A Neglected Aspect of Inflation (Washington, D.C.: American Enterprise Institute for Public Policy Research, 1975), Domestic Affairs Study, No. 28.

15This analysis abstracts from the heterogenetty of capital goods. 


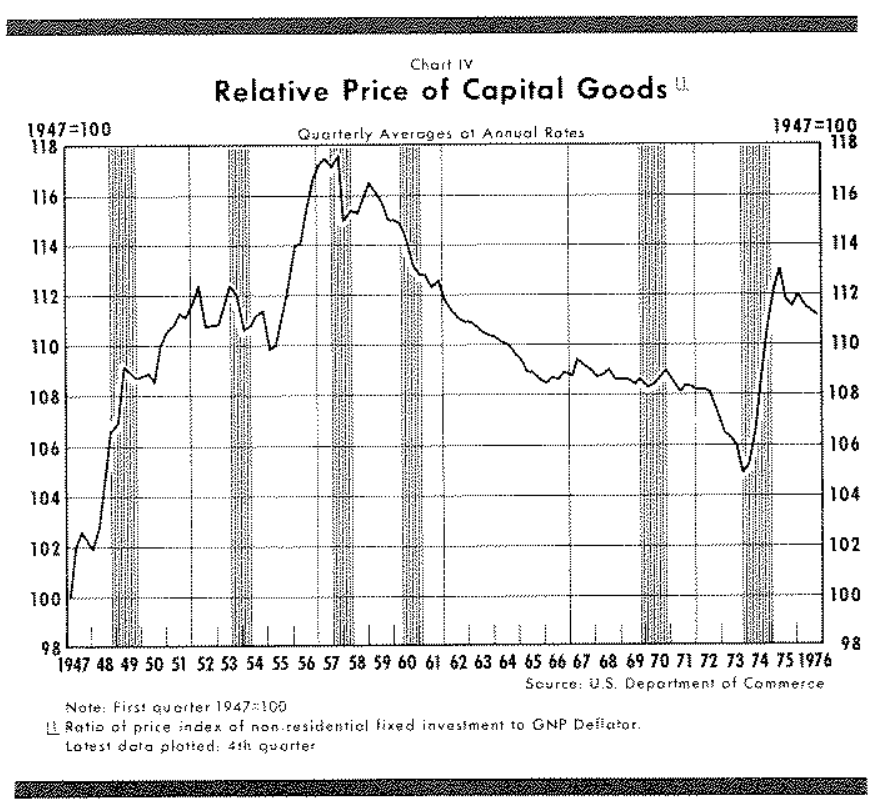

have a reliable index of the price of existing capital goods. However, there is likely to be a significant positive relationship between the movement in the (unobserved) price of capital goods and (observed) equity prices. The reasons are: the price of existing capital goods represents the present value of the expected net earning stream derived from them, and at the same time the value of ownership claims on corporations derives in part from the present value of the expected net earning stream of capital goods owned by the corporation. In view of the sharp decline in equity prices during the 1973-75 downturn, it is reasonable to infer that a price index of existing capital goods would have fallen, or at least, not have risen. In contrast, the cost of producing new capital goods has risen sharply, thereby making the acquisition of such goods less attractive in general. In addition, should such a unique experience regarding the price of capital goods increase uncertainty as to its future course, it wonld effectively foreshorten the time horizon for investment decisions. This would tend to reduce the desired capital stock by narrowing the menu of profitable investment opportunities.

\section{INVESTMENT DURING RECOVERY}

The improvement in business expectations (as reflected in the commitments data) regarding the net return on investments since the recession trough in March 1975 has been modest relative to the other recoveries (see Chart II). Six quarters into the recovery, commitments in real terms were more than 30 percent below the level attained at the previous reference peak. In the previous recoveries, however, the commitment levels attained at previous reference peaks were topped within two or three quarters, except for the 1970 episode when the full rebound to the previous peak was made in the sixth quarter of recovery.

The most important factor adversely impinging on business investment commitments in the current recovery has been the widespread concem shared by many businessmen for solvency and the state of balance sheets. That such a concem was well founded was underscored by the widespread, lingering incidence of business failures well into the current recovery. Business failures, as measured by the aggregate monthly amount of the current liabilities of failed businesses, reached a climactic high of $\$ 1,295$ million in October 1975, two quarters into the recovery. ${ }^{16}$ Such widespread business failures reflect a generally weakened balance sheet position of business firms, due variously to the recession-induced decline in profits and the inflation-induced increase in real tax liabilities.

For example, in an inflationary environment, the use of first-in first-out inventory accounting methods and the basing of depreciation charges on historical cost, overstate the extent of profits, thereby increasing the real tax liabilities. To compound the difficulties, many businesses were burdened with a debt-heavy capital structure, itself a legacy of favorable tax treatment of debt relative to equity capital.

The goal of solvency became a target of immediate concern in many business firms and the entailed strategy of repairing their balance sheet positions was adopted by many business firms. The debt structure was lengthened. Cash flows and the equity market were used to build up ownership claims and reduce indebtedness. In the process, the expansion strategy based on increased net investment outlays was temporarily deferred and the rebound in investment outlays lagged. ${ }^{17}$ Business cash flows were used to augment balance sheet positions rather than to increase spending on capital goods. ${ }^{18}$ The sustained improvement in the profitability index since 1975 has not yet

\footnotetext{
${ }^{16}$ For perspective, the highest postwar figure prior to the most recent recession was $\$ 253$ million in August 1972 .

${ }^{17}$ For an analysis of different types of grand business strategies, see William F. Glueck, Business Policy Strategy Formation and Management Action, 2nd ed. (New York: MeGraw-Hill, 1976), pp. 120-47.

18 For a recent account of balance sheet rebulding, see "Firms Spend Carefully, Pay Off Much Debt and Build Liquidity," The Wall Street Journal (January 13,1977 ), pp.1 and 8 .
} 
been mirrored either in the commitments data or in real investment outlays. ${ }^{19}$

\section{Oullook}

Recovery in the investment commitments data has been sluggish and so has the recovery in investment outlays in the current recovery to date. The slow recovery in the commitments data reflects the lag in revising upward the desired capital stock relative to the actual. But what of the outlook? Any upward revision in the desired capital stock probably would be reflected in the commitments data prior to the actual increase in the flow of investment outlays. Available data on business balance sheets, profitability, money and financial flows, and the behavior of the relative price of capital goods indicate that a sustained but modest improvement in investment commitments and outlays is in store.

An additional factor which bears on this likely course of investment outlays is the observed relationship between actual investment outlays and the particular kind of investment anticipations data called "first anticipations" of capital outlays published by the Commerce Department. ${ }^{20}$ The "first anticipations" series refers to the capital outlays business firms are planning to expend in the quarter immediately following the quarter in which the survey is taken. As such, it is even more closely correlated with the actual investment outlays than the commitments data. The reason is that the data reflect forecasts concerning how the outlays (which have been determined in the previous stages in the investment process concerning appropriations and placing of orders and contracts) would be allocated between the next quarter and beyond. The discrepancy between the actual and anticipated outlays reflects the same set of forces as that responsible for the aforementioned discrepancy between the investment commitments and the actual investment expenditures.

19The index is composed of adjusted corporate profits in 1972 dollars, the ratio of price to unit labor cost in manufactaring, and the stock price index. See Business Conditions Digest (November 1976), pp. 8 and 59. For a more detailed description of the behavior of aggregate business (corporate) balance sheet since 1960 , see Timothy Q. Cook, "Net Cor" porate Saving in the 1970 's," Economic Review, Federal Reserve Bank of Richmond (May/June 1976), pp. 3-13.

sof the commitments data, see Zarnowitz, Orders, Production, and Intestment, pp. 433-42; also Arthur M. Okun, "The Value of Anticipations Data in Forecasting National Product," The Quality and Economic Significance of Anticipations Data: A Conference of the Universities - National Bureat Committee fot Economic Research National Bureau of Economic Re. search (Princeton: Princeton University Press, 1960), especially pp. $433-42$.

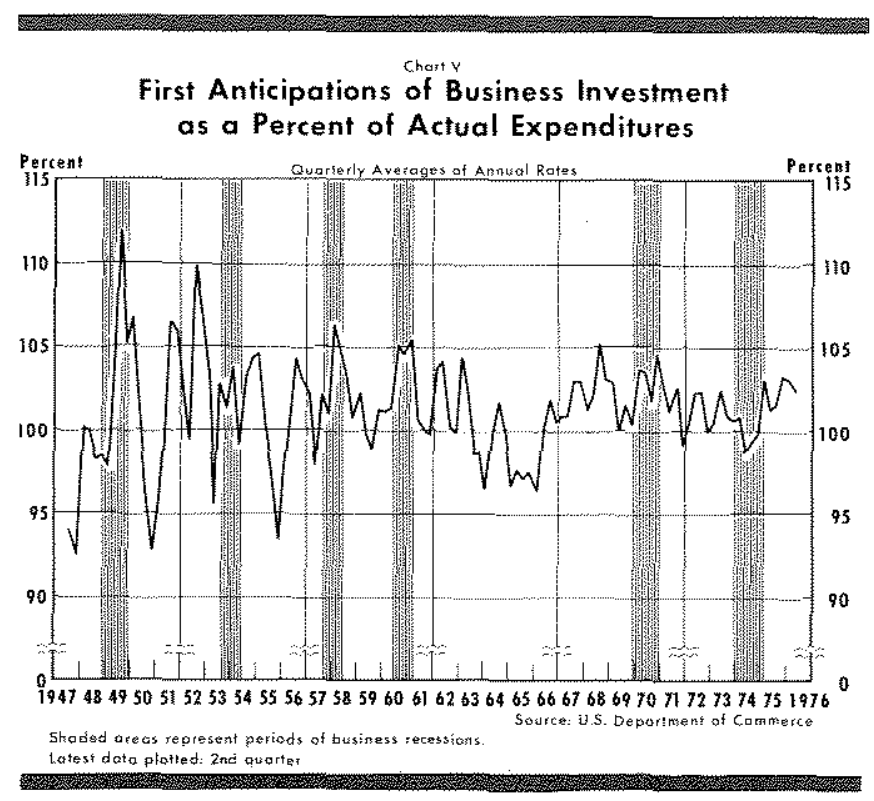

Chart V plots anticipated expenditures as a percent of actual expenditures. One-hundred percent indicates a perfect coincidence between the anticipated and the actual. Anything above 100 percent indicates a shortfall in actual relative to planned expenditures and vice versa. The chart shows that, in the current recovery, actual expenditures are yet to exceed the planned levels six quarters into the recovery.

Such a development is also unique in the postwar episodes. It appears to reflect the changes in the timing decisions (the deferral) of planned outlays rather than any substantial reassessment of prior decisions regarding the desired stock of capital. Such an interpretation appears reasonable, in view of 1) the behavior of the commitments data, 2) the fact that first anticipations data have steadily increased since the second quarter after the trough, and 3 ) the more than usual dose of uncertainty regarding the thrust of national economic policy. As the uncertainty regarding the economic policy environment (which was associated first with the presidential election and then with the thrust of the policy of the new Administration) recedes, the expected "catch-up" with this source of deferred outlays is likely to add strength to the recovery in investment outlays.

In sum, the near-term outlook for a gradual and modest rebound in business capital spending is favorable. However, it does not appear that capital spending will top the previous peak within the next two or three quarters, unless there is an unexpected shift in business expectations of net return on investment. Such a shift, should it occur, would be signaled first by a substantial rise in commitments - as yet, commitments have not emitted such signals. 